"actual" geometry of space, and he would probably âssent to Poincaré's dictum that the science of mathematics is neither true nor false.

There is one remarkable statement made which deserves mention. Dr. Mannoury says that in December, ISIS, F. K. Schweilkart sent to Gauss a note asserting the existence of a geometry in which the sum of the angles of a triangle is less than two right angles, and in which the altitude of an isosceles triangle with a finite base has a finite upper limit. This goes far to demolish the claim made for Gauss that he was the first to assert the possibility of a consistent system of geometry distinct from that of Euclid.

G. B. M.

\section{THE PROTOZOA: AN IMPRESSIONIST}

\section{SKETCH.}

Protozoölogy. By Prof. Gary N. Galkins. Pp. 349. (New York and Philadelphia: Lea and Febiger; (L.ondon: Baillière, Tindall and Cox, Igog.) Price $15 s$, net.

TO attempt to condense our present knowledge of I the Protozoa into some three hundred pages is to anyone acquainted with the subject-to attempt the impossible. This book, however,

"does not aim at being an exhaustive treatise on the Protozoa; it aims, rather, to give an introduction to the study of modern protozoology as seen from the author's point of view."

It would therefore be unfair to draw comparisons with Doflein's recent masterpiece on the subject which appeared almost simultaneously.

As we differ fundamentally from the author in many matters of interpretation-both as regards general principles and detailed facts-we can here consider only a few points which a perusal of the worls has suggested.

With regard to the tentative classification of the Protozoa which is adopted, we can only say that it is, perhaps, as good as any which has so far been advocated. With our present knowledge, it is not possible, we believe, to arrive at a satisfactory classification of the whole group. At present there must be many tadpoles among our fish. It mav be noted, however, that the author does not accept Hartmann's group "Binucleata"-for trypanosomes and their allies and Hamosporidia-and in this we heartily agree with him. It may be noted, further, that the Spirochats are classificd (with some reservation) among the Mastigophora; the Mycetozoa are ranked under the Rhizopoda; the Opalinidx are placed among the holotrichous Ciliata; and the Mastigamœbre are placed, in the order Monadida, with the Mastigophora. Though these groupings are usual, they are none the less, we believe, unjustifiable in the light of recent work.

In dealing with the trypanosomes, the author adheres to Schaudinn's much-debated work, because he finds

"the schematic figures and categorical descriptions of Schaudinn's original contribution are still the most convincing of all such attempts to describe the nuclear changes."

กั0. 2122 , voL. 83$]$
The life-cycle of Paramecium is described as a "typical" one. With this we cannot agree, because we consider the Ciliophora to be very different from all other organisms. Moreover, we regret to find no allusion to the recent important work of Enriques and others in this connection.

A remarkable account of autogamy in Amoeba limax is given, apparently from the author's own (unpublished?) observations, though no indication of this is given. Autogamy is again alleged to take place in Amocba proteus, though this has not been by any means proved. It is disappointing to find no reference, in this connection, to Prandtl's important work on Cryptodifflugia ("Allogromia").

It seems to us that undue prominence has been given to many very questionable organisms, such as "Cytorrlyctes z'ariolae," the "Negri bodies," \&.c. (described, by the way, under "Parasitic Rhizopoda"), whilst many important life-histories, e.g. Opalina, Mastigella, Trichosphærium, Stylorhynchus, \&c., receive little more than passing mention.

The remarkable form Aggregata is mentioned only in the classification, where it is placed among the cephaline gregarines! One can only suppose that this is an oversight; and we regret to see that the very doubtful work of Dallinger and Drysdale has found its way into yet another text-book.

Throughout the book, generic names are often written in ordinary type, without a capital letter, although in many cases the customary convention is adopted-frequently in the same paragraph. We think this is to be deplored, more especially so because medical men-to whom, on account of the large amount of space devoted to parasitic forms, the book will specially appeal-are at present particularly prone to write zoological names incorrectly. In addition, the author's apparent dislike of diphthongs causes him to adopt the spellings not only Paramecium (correctly), but also Ameba, Actinospherium, Spirocheta, S.c., and even Jenia (for Joenia).

These criticisms are, however, of minor points. The chief value of the book lies in the fact that it gives us a unified picture of the many problems of protozoology as they present themselves to a worker who has deroted many years of original research to his subject. Without doubt, the book will be welcomed by many, because there exists no other modern work in English which attempts to deal with the present state of protozoology within the compass of a single volume.

C. Clifford Dobell.

\section{BEE-KEEPING IN AMERICA.}

How to Keep Becs for Profit. By Dr. D. E. Lyon. Pp. xii+329. (New York: The Macmillan Conpany; London: Macmillan and Co., Ltd., I910.) Price 6s. 6d. net.

THIS is a book on bee-lieeping in the United States. 1 The author is a well-known bee-keeper, and an entertaining writer; he has a happy way of briefly explaining the chief operations of the apiary in a personal style that does not weary the reader. Dr. Lyon tells us that many vears ago he acquired the "bee fever," "from which he has never recovered, 